\title{
Lisanslı Depoculuk Sisteminin İşleyişi ve Türkiye'de Uygulanabilirliği
}

\section{Selma KARABAȘ ${ }^{\mathrm{a}}$ \& A. Zafer GÜRLER}

\section{Özet}

Gelişmiş ülkelerin tarım piyasaları incelendiğinde, ürün borsacıllğından türev piyasalara geçiş yapıldığı görülmektedir. Türkiye de gelişmekte olan bir ülke olarak, rekabete açık serbest piyasa ekonomisinin gereklerini yerine getirmek durumundadır. Dünyanın ekonomide kurtuluş olarak seçtiği rekabete açık serbest piyasa ekonomisinin merkezinde ürün borsaları yatmaktadır. Ürün borsaları ile lisanslı depoculuk birbirinden ayrılmaz bir bütündür. Türkiye'de de lisanslı depoculuk ve ürün borsacıllığ uygulanmasıyla, türev piyasalara altyapı hazırlanmış olacaktır. Lisanslı depolama sistemi ile ürün standardı sağlanarak, ürünler sağlıklı koşullarda saklanabilecek ve üreticiler arzın kısa bir döneme yığılması sebebiyle düşük fiyat riskinden korunmuş olacaktır. Bu çalışmanın amacı, lisanslı depoculuk sisteminin işleyişi, avantaj ve dezavantajları ve sistemin Türkiye'de uygulanabilirliğini ortaya koymaktır.

Anahtar Kelimeler: Lisanslı Depoculuk Sistemi, Makbuz Senedi, Ürün Borsası

\section{The Mechanism of Licensed Warehousing System and its Applicability in Turkey}

\begin{abstract}
When the agricultural markets of developed countries are examined, it can be seen that there is a transition from the commodity exchanges to the derivotive markets. Therefore, Turkey, as a developing country, should fullfill the requirements of a free-market economy. The free-market economy, which is considered as a means of the survival for many economies, includes the specialized exchanges in its center. On the other hand, the specialized exchanges and licensed warehousing are inseperable. Therefore, the applications of the specialized exchanges and licensed warehousing system will be the foundations of the derivative markets in Turkey. Through the licensed warehousing system, the products the products will be standardized and they can be kept in healthy conditions. Thus, the producers hedge against the lower price risk of short-run supply pressures. The purpose of this study is to determine the processes, advantages and disadvantages of the licensed warehousing system and its application in Turkey.
\end{abstract}

Key words: Licensed Warehousing System, Receipts Act, Specialized Exchange

\footnotetext{
a Öğr. Gör., Gaziosmanpaşa Üniversitesi, Artova MYO, selmak@gop.edu.tr, Tokat.

${ }^{\mathrm{b}}$ Prof. Dr., Gaziosmanpaşa Üniversitesi, Ziraat Fakültesi, zgurler@gop.edu.tr, Tokat.
} 


\section{Giriş}

Türkiye'de 2000'li yıllara kadar tarım sektöründeki desteklemeler, üretim maliyetlerini etkileme, düşük faizli kredi kullandırma ve müdahale alımları gibi politikalar aracılığıyla gerçekleştirilmiş; 2001 sonrasında ise destekleme alımları sınırlandırılmış, tarımsal kredi faizleri piyasa faizleri düzeyine yükseltilmiş ve üreticilere "Doğrudan Gelir Desteği (DGD)" adı altında tek bir tarım politikası aracı ile kaynak aktarılmaya başlanmıştır (İnan, 2001). Avrupa Birliği üyesi ülkeler tarımsal üretimde kendine yeterliliği yakalayabilmek için değişik politika araçlarılya yıllarca üreticilerine destek sağlamış; stoklama maliyetlerinde meydana gelen aşırı yük, üretim miktarındaki artıştan sağlanan gelirden büyük olunca, destekleme politikalarında değişikliğe gidilmiş, fakat hiçbir zaman tek bir tarım politikası aracı kullanılmamıştır. Dünyada gelişmiş ülkelerin serbest piyasa ekonomisini tüm sektörlerde olduğu gibi tarım sektöründe de uygulaması ile, tarım ürünleri ticareti devlet tarafından değil, özel firmalarca yapılmaya başlanmış ve Türkiye de dünyadaki gelişmelere seyirci kalamamıştır.

Serbest piyasa ekonomisinin gereği olan ürün borsaları ile paralel çalışacak olan lisanslı depoculuk sistemi; tarım ürünlerine dayalı ticareti kolaylaştıran, tarımsal ürünler için yurt çapında yaygın bir depolama sistemi oluşturan, mudilere mallarının emniyeti ve kalitesi ile ilgili güvenilir koruma sağlayarak pazar alanını genişleten, piyasalarda fiyat istikrarına katkı sağlayan ve ekonomide kayıt dışının önlenmesinde önemli bir araç olan çağdaş bir kurumsal altyapıdır. $\mathrm{Bu}$ sistemi kuramayan ülkeler, içinde bulunduğumuz küresel ekonomik düzende büyük ölçüde bu sistemi kuran gelişmiş ülkelerin bağımlı ve ikincil pazarı haline gelmektedir (Hekimoğlu ve Altındeğer, 2006). Sistem, arzın zamana yayılarak üreticiye yüksek fiyattan ürününü satabilme, işleyici ve sanayici için istenilen kalite ve miktarda hammadde sağlayabilme imkanı sunmasının yanı sıra, spot piyasadan türev piyasalara geçişte önemli bir altyap1 hazırlayacaktır. Lisanslı depoculuk, ürün borsacılığı ile paralel çalışacağından, borsacılığın geliştirilmesi açısından da konu oldukça önemlidir.

$\mathrm{Bu}$ çerçevede çalışmanın amacı; Türkiye-Avrupa Birliği uyum sürecinde uygulamaya konulan yapısal reformlar ve düzenlemeler sonucu ortaya çıkacak duruma uyum sağlamak ve kamunun piyasalardaki müdahaleciliğinden vazgeçmesi ile oluşacak boşluğu doldurmaya hazırlanmak için, tarımsal ürünlerde lisanslı depoculuk sisteminin avantaj ve dezavantajları ile ürün 
borsalarının sistem içindeki yerini belirlemek ve sistemin Türkiye'de uygulanabilirliğini ortaya koymaktır.

\section{Lisanslı Depoculuk Sisteminin İşleyişi}

İlk etapta buğday ve pamuk ile başlayacak olan ürün borsacılığı ile ürün borsalarından gelen emtianın lisanslı depolara teslimi yapılacak, tartım ve analiz işlemlerinden sonra bu malların karşıllı̆̆ olarak bir elektronik senet veya yazılı bir makbuz senedi verilecektir. Ürünün adı, miktarı, kalitesi vb. bilgileri içeren makbuz senedi ürün borsalarında el değiştirebilecek, ciro edilebilecek ve teminat karşılığ 1 kredilendirme işlemlerinde kullanılabilecektir. Lisanslı depoculuğun en önemli aracı olan makbuz senedi üzerinde yer alması gereken bilgiler aşağıda verilmiştir (Grange, 2002):

- Ürünün miktar, kalite ve çeşidi,

- Depolanan ürünün kime ait olduğu,

- Ürünün depolandığı yer ve sigorta ile ilgili bilgiler,

- Çiftçi, tüccar, işleyici, depo işletmecisi ve tüm mudilerin arasında depolama sözleşmesinin şartları ve depo makbuzunun özelliği.

Ürününü lisanslı depoya teslim ederek karşı1ığında makbuz senedi alan mudinin üç ayrı seçeneği bulunmaktadır. İlk olarak; mudi lisanslı depoya teslim ettiği ürün karşıllı̆̆ almış olduğu makbuz senedini bankaya rehin koyarak kredi kullanabilecektir. İkinci olarak; mudi makbuz senedini borsada satı̧a sunabilecek ve son seçenek ise; ürününü pazarlık ederek lisanslı depoya satabilecektir. Ürününü lisanslı depoya teslim eden üretici ya da tüccarın ürününün sigorta kapsamına alınması ürün sahibi açısından önemli bir avantaj sağlayacaktır.

\subsection{Lisanslı Depoculuk Sisteminin Temel Araçları}

Tarım piyasalarının geliştirilmesinde önemli bir araç olan lisanslı depoculuk sistemi içerisinde kanunda tanımlanan ve depolamaya uygun niteliğe sahip "tarım ürünü", ürünleri özelliklerine göre sinıflara ayıran "yetkili sinıflandırıcı", ürünlerin sağlıklı koşullarda depolanmasını sağlayan "lisans almış depolar", mudinin ürününü teslim etmesi karşılığı kıymetli evrak niteliği taşıyan ve borsada işlem yapabileceği ya da rehni karşıllğı bankadan kredi kullanabileceği “makbuz senedi" ve "borsa" yer almaktadır (Anonim, 2005). 


\subsection{Sistemde Yer Alan Kuruluşlar ve Rolleri}

Sistem içerisinde; ürünü alıp-satan üreticiler, tüccarlar, spekülatörler, sanayiciler, ürünün sağlıklı koşullarda depolanmasını sağlayan lisanslı depolar, ürünün fiziksel olarak yer değiştirmeden el değiştirerek işlem yapılabileceği ürün borsaları, makbuz senedi karşılı̆̆ kredi sağlayacak bankalar, lisanslı depoda bulunan ürünü sigorta edecek şirketler ve sistemi düzenleyen ve denetleyen Sanayi ve Ticaret Bakanlığı yer almaktadır.

Bir lisanslı deponun kurulabilmesi için; anonim şirket olması, Bakanlıktan kuruluş ve faaliyet izninin bulunması, depolama kapasitesine göre en az 1 trilyon TL ödenmiş sermayenin olması, depo kapasitesinin ürün rayiç bedelinin \% 15'inden az olmamak üzere teminat, işletme tesislerinin ve depolanan ürünlerin sigorta zorunluluğu, ilgili borsa ile sözleşme yükümlülüğü ve yönetmelikte gösterilen diğer şartlar ile teknik gereklilikler olması gerekmektedir.

Ucuz maliyetle ürün sahiplerine (üretici, tüccar, sanayici vd.) güvenli depolama imkanı sunan lisanslı depoya gelen ürün, laboratuar testleri sonucu kalitesine göre sınıflandırılarak tartılır ve ilgili kaliteye ayrılmış bölümlerde stoklanır. Yapılan standardizasyona göre aynı kalite aralığına düşen farklı mülkiyete konu ürünler aynı bölümde stoklanır. Yani her üreticinin ürünü ayrı ayrı stoklanmaz ve kimse teslim ettiği ürünü isteyemez. Sadece aynı kalitede ürünü depodan geri alabilir. Ürünün kalitesinin belirlenmesi ve sınıflandırılması yetkili sınıflandırıcılar tarafından yapılacaktır. Bunların analiz sonuçları üzerinde bir ihtilaf ortaya çıkması durumunda referans laboratuarlar devreye girecektir.

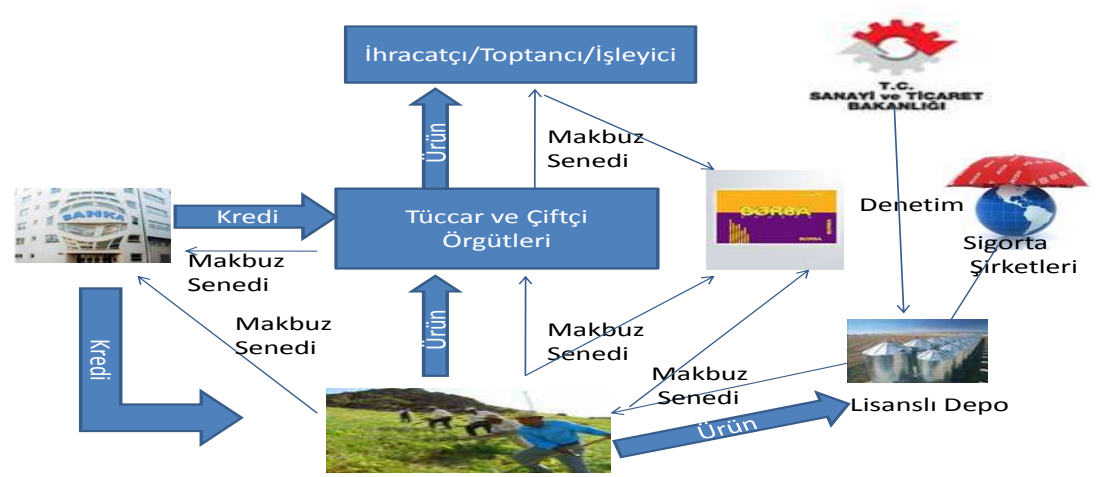

Şekil 1. Sistemde Yer Alan Kuruluşlar (Lacroix ve Varangis, 1996; USAID, 2005 ) 
Makbuz sahibi, piyasa fiyatlarının durumuna ve piyasadan beklentilerine göre makbuzu satmak yerine, güncel ihtiyacı olan likiditeyi sağlamak amacıyla makbuz karşılığı bankadan kredi alabilir. Aynı işlemi tüccarlar ve sanayiciler de likidite yaratmak için yapabilirler. Böylece, stoklarda bekleyen bir değer, piyasa içinde aktif hale getirilmiş olur.

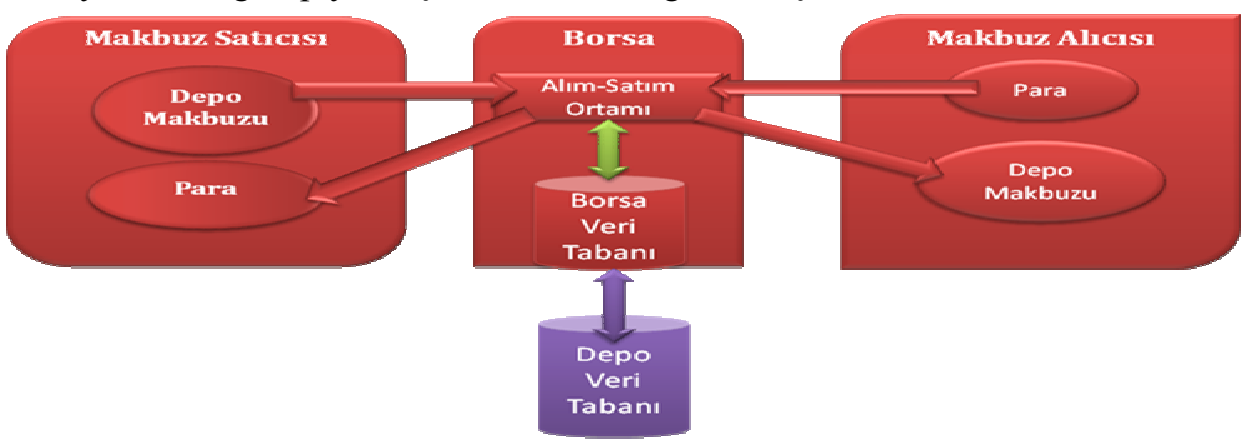

Şekil 2. Depo Makbuzunun Borsada İşlem Görmesi (Demirbilek ve ark., 2006)

\subsection{1. Ürün İhtisas Borsalarının Lisanslı Depoculuk Sistemi İçindeki Yeri}

Lisanslı depoculuk sisteminin en önemli ayağı ürün borsalarıdır. Tarım piyasalarının geliştirilmesi, fiyatların serbest rekabet koşullarında oluşması, arzın zamana yayılması, kaliteli ve standart ürün üretiminin teşviki için yöresel ya da bölgesel değil, ulusal çapta işlevsel olan ürün borsalarının oluşturulması gerekmektedir. Lisanslı depoculuğu tek başına düşünmek mümkün değildir. Sistem, ürün borsacılığı ile iç içe çalışmaktadır. Borsaya ürününü getiren üreticiye lisanslı depo işletmecisi tarafından kıymetli evrak niteliğini taşıyan bir makbuz senedi verilerek, ürününü kendisi için makul bulduğu bir fiyattan satma imkanı sunan depoculuk sitemi ile depolanan ürün de sigortalanmış olacaktır. Ticaret borsalarının bulundukları bölgede yetiştirilen ürün bazında ulusal çapta ihtisaslaşmasının sağlanması ile lisanslı depoculuk sisteminin çatısı oluşturulmuş olacaktır. Lisanslı Depoculuk Kanununda borsa, ürün senetlerinin kota ettirildiği ya da alım satımının yapıldığı ürün ihtisas borsası veya Bakanlıktan ürün senedi alım satımı konusunda izin alan ticaret borsası olarak tanımlanmaktadır.

Türkiye'de tarım piyasalarındaki en önemli unsurlar; Devlet, Tarım Satış Kooperatifleri Birlikleri, Ticaret Borsaları ve aracılardır. Tarımsal ürünler ticaretinin ve piyasaların gelişmesinde borsaların varlığı son derece önemlidir. Ticaret Borsaları, bulundukları yerlerde üretimi, tüketimi ve pazarlaması yeterli kapasitede olan maddelerin alım-satımının, fiyatların serbest rekabet düzeni 
içinde tespit ve ilanı işleriyle meşgul olan organize pazarlardır. Türkiye'deki 114 adet ticaret borsasından yaklaşık 10 kadarı sahip oldukları laboratuarlarda, ürünleri kalite özelliklerine göre sınıflara ayırmakta ve salon satışı yaparak işlevini yerine getirmektedir. $\mathrm{Bu}$ sayede fiyatlar rekabet ortamında oluştuğundan, üretici ya da tüccar ürününü gerçek değeriyle alıp satabilmektedir. Borsaların işlevlerini yerine getirmemeleri, üretici için düşük fiyat riski, tarımsal ürünleri hammadde olarak kullanan işleyici ve sanayici için de bol miktarda ve kaliteli hammadde bulamama riski doğurur. Diğer taraftan, borsalar ülke ekonomisi için önemli bir sorun olan kayıt dışı ile mücadelede de önemli bir araçtır. Buğday ve pamuk dahil tarım ürünlerinin küçük bir bölümü borsa satış salonlarında alınıp satılmakta, büyük bölümü ise kayıt dışı olarak ticarete konu olmaktadir (Anonim, 2009a) .

5590 sayılı kanuna göre, ticaret borsalarına dahil maddelerin alımı ve satımı ile iştigal edenler, bulundukları yerin ticaret borsasına kaydolmaya mecburdurlar. Ancak Ticaret Borsası bulunmayan bir piyasada üretici veya tüccar Maliye'ye \%4 zirai stopaj ödemektedir. Ticaret borsasının bulunduğu, ancak sadece tescil işlemi yaptığ bir piyasada, tüccar ya da sanayici maliyeye $\% 4$ yerine $\% 2$ vergi ödemek amaciyla ürününü o günkü değerinden tescil ettirerek vergi avantajı sağlamak için borsaya yönelmektedir. Türkiye'deki ticaret borsalarından çok azında satış salonunun yanı sıra ürünlerin satış salonuna girmeden laboratuar ortamında analiz edilmesine firsat tanıyan sistem vardır. Üretici, tüccar ya da sanayicinin ürünü ticaret borsasındaki satış salonuna girmeden laboratuardan geçmekte ve kalite özelliklerine göre ürünlerin fiyatı oluşmaktadır. İşlevini yerine getirebilen bir ticaret borsası aşağıda görüldüğü gibidir ( Demirbilek ve ark., 2006).

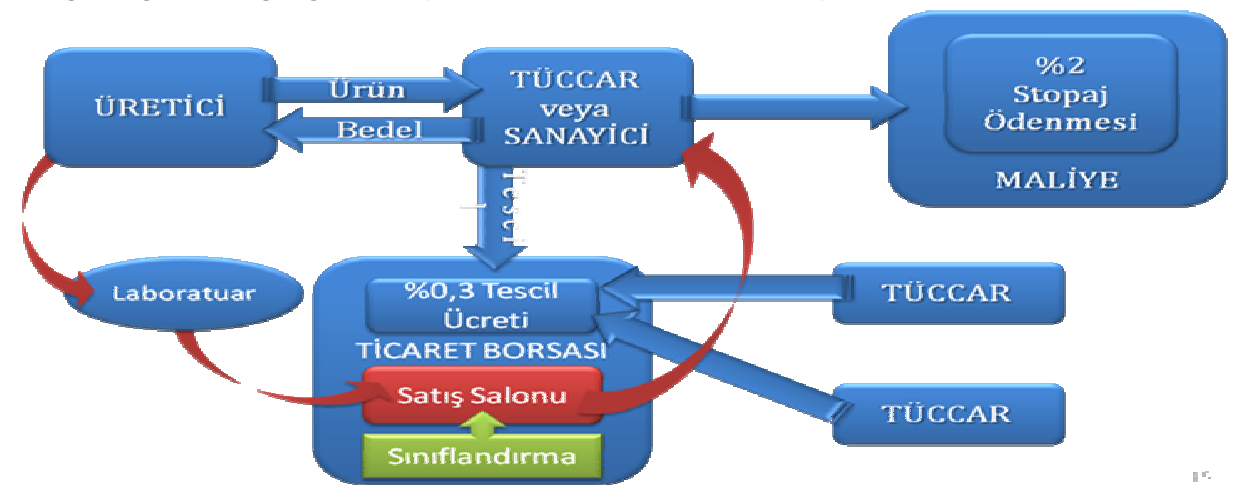

Şekil 3. Laboratuar Sonuçlarına Göre Sınıflandırma Yapılan Salon Satışı (Demirbilek ve ark., 2006). 
Ticaret borsalarının işlevsel olmamalarının nedenleri; üreticilerin borsalar hakkında yeterli bilgi sahibi olmamaları, nakit ihtiyacını tüccardan karşılayan üreticinin ürününü, tüccarın önerdiği fiyattan satmayı kabullenmek durumunda kalması, ticaret borsalarının ürünün taşınması ve satışı için uygun mekana sahip olmaması, teknik altyapı eksiklikleri ve başta hububat olmak üzere bazı tarım ürünlerinde devletin piyasaya girerek çok yüksek miktarlarda müdahale alımı yapması, piyasada sağlıklı fiyat oluşumuna izin vermemekte ve borsaya yönelebilecek ürün miktarını kısıtlamaktadır (İnan ve ark., 2003).

$\mathrm{Bu}$ sorunların giderilmesi için; borsaların altyapı imkanlarının geliştirilmesi, lisanslı depoların kurulmasıyla birlikte, makbuz senetlerinin borsalarda işlem görebilmesinin sağlanması, vergi muafiyetleri ve üretici ya da tüccarın borsada işlem yapmalarını özendirecek şekilde teşvik edilmesi gerekmektedir.

\subsection{Lisanslı Depoculuk Sisteminin Avantajları}

2005 yılında yasalaşan ve mevzuat altyapısı tamamlanan Lisanslı Depoculuk Sistemi ile tarım piyasalarında fiyatlar sağlıklı şekilde oluşacak, üretimin pazarlanması zamana yayılacak, kamu piyasalardan çekilerek düzenleyici ve denetleyici rol üstlenecek, yeni finans ve yatırım araçları oluşacak, kaliteli üretim teşvik edilecek, yeni istihdam alanları gelişecek ve borsaların spot piyasa işlemlerinden forward ve futures işlemlere geçişi kolaylaşacaktır. Sistemin sağlayacağı avantajlar aşağıda ayrıntılı larak verilmiştir.

\subsection{1. Üreticiler Açısından Avantajları}

- Üreticiler güvenli, sigortalı ve sağlıklı koşullarda ürünlerini saklama imkanı bulacaktır. Sağlıklı koşullarda depolama sistemi ile ürün kalitesi de olumlu etkilenecektir (Faber ve Koster, 2002:382).

- Üretici ürünü hasat zamanı düşük fiyattan satmak yerine lisanslı depoda saklayarak fiyat yükselişlerini takip edebilecek ve kendisi için uygun bir zamanda ürününü satabilecektir. Ya da üretici ürününü lisanslı depoya teslimi karşılığ almış olduğu makbuz senedini bankaya rehin koyarak finansman ihtiyacını karşılayacak krediyi sağlayabilecektir.

- Tarım ürünleri objektif laboratuarlarda kalite özelliklerine göre standardize edilecek, kaliteli ürün yüksek fiyattan pazarlanabilecektir. Böylelikle üretici kaliteli ürün üretimine teşvik edilmiş olacaktır. 
- Sanayici depo kurma maliyetinden kurtularak en yakın lisanslı depoyu kullanabilecek, böylelikle tasarruf sağlanmış olacaktır.

- Depoya ürün teslimi karşılığı alınan kıymetli evrak niteliğindeki makbuz senetleri ticarete konu olabilecek, ürün yalnızca yerel pazarlara değil, elektronik ortamda ulusal ve uluslar arası düzeyde pazarlara açık olacaktır.

- Talep miktarı, türü ve ürün kalitesi güvenli ve elektronik ortamda kısa sürede sağlanacaktır (Ulaş, 2007).

- Depo, banka ve borsa arasında sağlanacak güçlü iletişim ağı ile mevcut talep, stok miktarı ve teslim edilen emtianın belirtilen tarih ve sözleşmeleri ile eşleştirilebilmeleri sağlanacaktır. Küçük üreticileri belli bir standartta üretime teşvik edecek ve böylece modern ve etkili pazarlara açılabileceklerdir. Ayrıca depolama sisteminin kullanımı tarım ürünleri ticaretine şeffaflık kazandıracak, üretici, işleyici, sanayici ya da tüccar arasındaki dağıtım zincirinin kısalmasını sağlayarak pazarlama marjlarının daralması sağlanacak ve fiyat dalgalanmalarının önüne geçilmiş olacaktır (Coulter ve Onumah, 2002:326).

\subsubsection{Borsalar Açısından Avantajları}

- Sistem sayesinde ürün alıcı ve satıcıları geniş bir platformda ürünlerin gerçek değerlerine göre fiyatlarının oluşumuna ve işlem hacimlerinin artışına katkıda bulunacaklardır.

- E-Ticaret ürün ticaretini geliştirecek ve borsalar temel ilgi alanlarına dönerek modern yapılarını kazanacaklardır.

- Güçlü ve modern borsa yapısının yanı sıra, diğer ülke pazarlarına açılmak ve ülkemizde ticari payı yüksek olan ürünlerinin pazarlaması kolaylaşacaktır.

- Ülkede yalnızca tescil ofisi görevi yapan ve etkisiz durumda olan ticaret borsaları etkin hale gelerek uzmanlaşmaları teşvik edilecektir.

\subsection{3. Ülke Açısından Avantajları}

- Sürmekte olan Tarım Reformu Uygulama Projesi (ARIP) ile Ürün İhtisas Borsaları Geliştirme Projesi ve Lisanslı Depoculuk Sistemi vasıtasıyla, ürün pazarlamada özel sektör daha aktif hale getirilmiştir (Ulaş, 2007).

- Devlet kamu alımlarından çekileceği için, bu ürünlerin pazarlama sorunlarının çözülmesine katkı sağlayacaktır. 
- Depolamaya uygun nitelikteki ürünlerin satın alma ve depolama maliyetleri düşecektir.

- Üretim miktar ve kalitesi ile ilgili sağlıklı bir veri tabanı oluşturulabilecek ve buna uygun tarım politikaları geliştirilebilecektir.

- Sistem sayesinde, üretilen ve pazarlanan ürünler kayıt altına alınacak, bu da vergi kaybını önleyecektir.

- Tarımsal ürün üretiminde kalite ve standart sağlanacak, dış ticarette yaşanan sorunlar bertaraf edilecektir.

- Bankacılık ve sigorta sektöründe yeni istihdam alanları açılacaktır.

\subsubsection{Piyasalar Açısından Avantajları}

- Depo makbuzu ile döviz, altın, faiz gibi yatırımlara alternatif bir yatırım aracı ortaya çıkacaktır.

- Lisanslı depo sistemi ile vadeli piyasalara geçiş etkinleştirilecektir.

- Elektronik ticaretle önemli bir Pazar potansiyeli oluşturulacaktır.

- Ürün analizi, depolama, sigorta ve kredi kullanımı nedeniyle yeni gelir ve iş alanları açılmış olacaktır.

- Ürün ihtisas borsaları ve lisanslı depo şubelerinin açılmasıyla, yurtiçi ve uluslararası ürün pazarlama ve dağıtımı kolaylaşacaktır.

\subsection{Lisanslı Depoculuk Sisteminin Dezavantajları}

Lisanslı depoculuk sisteminin hayata geçmesi; piyasalar, üretici/sanayici/tüccar ve ülke ekonomisi açısından birçok avantajlar sağlamasının yanında bazı dezavantajları da barındırmaktadır. Sistemin teknik ve hukuki altyapısının iyi oluşturulamamış olması sağlıklı işleyişi engelleyecektir. Sistemin dezavantajlarına aşağıda yer verilmiştir.

- Küçük üreticinin depoya koyacak miktarda ürünü olmadığından, ilave bir depo masrafina katlanabilecek gücü yoktur (Uras, 2006).

- Sistemin işlemesi için her üretim merkezinde çok sayıda lisanslı depo olması gerekir, ancak ülkemizde faaliyete geçen lisanslı depo henüz yoktur (Uras, 2006).

- Lisanslı depoya konulacak ürünler için belli bir standardizasyon sistemi oluşturulamamıştır.

- Makbuz senedi karşılığı mudiye kredi sağlayacak bir banka mevcut değildir. 
Karabaş, S. \& Gürler, A.Z. / Sosyal Bilimler Araştırmaları Dergisi. 1, (2010): 196-210

- Lisanslı depoya teslim edilen ürünü sigorta edecek bir şirket bulunmamaktadır.

- Ülkemizdeki ticaret borsaları tescil ofisi niteliğinde olup, etkin değildir.

- Makbuz senetleri sürekli olarak el değiştirdiğinden sistemin sorunsuz işleyebilmesi için, banka, borsa ve lisanslı depo arasında etkin bir bilgi işlem ağı kurulması gereklidir, ancak bu yönde bir altyapı çalışması bulunmamaktadır.

\subsection{Lisanslı Depoculuk Sisteminin Tarım Ürünleri Piyasalarına Etkileri}

Hasat döneminde büyük miktarlardaki ürünün piyasaya arzı nedeniyle fiyatların düşmesi, hasat dönemine borçlanarak giren üreticinin ivedi finansman gereksinimi nedeniyle ürününü bu düşük fiyat düzeyinden elinden çıkarması, bu süreçte sonbahar aylarında spekülasyon hareketlerinin etkisiyle ürün fiyatlarının yükselmesi ve bunun tüketici fiyat düzeyine olumsuz etki etmesi, işleyicinin zamanında uygun fiyatla aradığı kalitede hammadde sağlamasındaki güçlükler, kamu finansman zorlukları tarım ürünleri pazarlama sisteminin öne çıkan sorunları olarak sayılabilir (Erbay, 2006).

Tarım ürünleri piyasasında cari yıla ait ürün arzı bir önceki yıla ait fiyatların fonksiyonudur. Bu nedenledir ki tarım ürünleri piyasasında fiyatlar arz miktarına bağlı olarak yıldan yıla sürekli bir dalgalanma göstermektedir. Bu durum üreticiler açısından önemli bir fiyat riski yaratmaktadır (Gürler, 2008). Tarımsal piyasalarda üretim planlaması yapılamadığı için üretici zarara uğramaktadır. Lisanslı depoculuk sisteminin hayata geçirilmesi ile üretim planlaması yapılabilecek ve ülke ekonomisi açısından üretilen ürünlerin katma değerleri yükselecektir.

Lisanslı Depoculuk Sistemi ile tarım ürünleri piyasalarına ve borsacılık sistemine önemli bir işlev kazandırılmış olacaktır. Bu depolardan ürün karşılığı verilen makbuz senetleri borsalarda işlem görebilecek ve ürün fiziksel olarak hareket etmeden kolaylıkla el değiştirebilecektir. Sanayici açısından düşünüldüğünde piyasa ve fiyat oluşumları ile ilgili kararlarını vadeli işlem piyasaları ile destekleyebilecektir. Aynı zamanda belli standartlarda ve kalitedehammadde ihtiyacının karşılanması açısından da lisanslı depoculuk sistemi önemli görülmektedir. Lisanslı depoculuk sisteminden verilen makbuz senetlerinin dolaştığı piyasada ürünler, kalite özelliklerine göre pazar bulabilecek ve belli standartlara sahip olan kaliteli ürün daha fazla gelir 
getirecektir. Bu durum üreticileri kaliteli ürün üretmeye teşvik edecek ve diş ticarette standardizasyon konusunda ülkemizin yaşamış olduğu sorunların önüne geçilmiş olacaktır.

\section{Türkiye'de Lisanslı Depo Uygulamaları}

Dünya Bankası ile birlikte yürütülen "Tarım Reformu Uygulama Projesi" (ARIP) kapsamında lisanslı depoculuk için onay verilen beş adet Tarım Satış Kooperatifi Birliğinden TARIŞ Zeytin ve Zeytinyağı Birliği, Dünya Bankası ile yapılan mutabakat kapsamında 21 bin tonluk depolama kapasitesi oluşturmak için lisanslı depoculuk yapabilme iznini almış ve çalışmalarına başlamıştır (Anonim, 2009b). Ayrıca Marmarabirlik, TARİş Üzüm Birliği, Çukobirlik ve Trakyabirlik de \% 50 maliyeti Dünya Bankası tarafından sağlanan finansman desteğiyle lisanslı depoculuk sistemini TMO yedi yıl kira garantisi vererek 35 ilde girişimcilere lisanslı depo kurduracaktır. Bu doğrultuda Türkiye'de ilk lisanslı depo; TMO, TOBB, Tarım Kredi Kooperatifleri Merkez Birliği, Umumi Mağazalar Türk A.Ş. ile Gümrük ve Turizm Şirketi tarafindan kurulmuştur (Anonim, 2007).

TMO bu yapı içerisinde depoların ilk beş yıl tüm kapasitesini, sonraki iki yıl da yarım kapasitesini kiralayacaktır. Bankalar da TMO'nun kiralama garantisini dikkate alarak yatırımcılara uygun koşullarda kredi kullandıracak ve ayrıca yatırımcılara arsa kolaylığ 1 sağlanacaktır.

İzmir Ticaret Borsası lisanslı depoculuk şirketi kurma çalışmalarına (pamuk için) 2009 yılında başlamış ve şirket kuruluşunun ardından, lisans alma çalışmalarına devam etmektedir (Anonim, 2010).

\subsection{Lisanslı Depoculuk Sistemine Verilen Teşvikler}

Lisanslı Depoculuk yatırımlarının vergi düzenlemeleri ile teşvik edilmesi amacıyla Ticaret ve Sanayi Bakanlığı öncülüğünde Maliye Bakanlığ1 nezdinde sonuçlandırılan düzenlemeyle lisanslı depoya teslim edilen ürün için üreticiye verilen ürün senetleri KDV den süresiz, Gelir ve Kurumlar Vergisi'nden ise 31 Aralı 2013 tarihine kadar istisna tutulacaktır. Lisanslı depoculuk işletmesi ile mudi arasında yapılacak sözleşmeler ve ürün senetleri Damga Vergisinden istisna tutulacaktır. İşletmelerin çalıştırdıkları Ar-Ge personeli için gelir vergisi stopaj1 ise \%90'a kadar indirimli ödenecektir (Anonim, 2009c). 


\subsection{Sistemin Uygulamasına İlişkin Sorunlar}

Türkiye'deki tarım piyasalarındaki işleyişte kamu, müdahaleci bir rol üstlenmektedir. Sistemin uygulamaya geçmesiyle birlikte kamu tamamen piyasadan çekilerek, özel sektörü piyasalara yönlendirecektir. ABD'deki lisanslı depoculuk uygulamalarına bakılacak olursa kamunun piyasalardan tamamen çekilmediği, çeşitli araçlarla piyasaları destekleyici ve düzenleyici rol aldığı gözlenecektir. Ayrıca ABD'de sistemin bu derece başarılı olmasının altında yatan en önemli sebeplerden biri de çok sayıda lisanslı deponun bulunması ve ürün standardının sağlanmış olmasıdır. Ancak Türkiye'de aynı bölgede dahi ürün standardı sağlanamamıştır ve ticaret borsaları işlevsel değildir. Ürün borsalarının sisteme entegre edilemediği bir sistemde çok sayıda lisanslı deponun kurulması dahi sistemin başarılı olmasını sağlamada yetersiz kalacaktır.

Sistemle ilgili teknik, hukuki ve bilişim ile ilgili altyapı sorunları henüz aşılamamıştır. Sistemde makbuz senetlerinin işlem göreceği borsalar oluşturulamamış, ürün senedi karşılığı kredi sağlayacak bankalar ve ürünü sigorta edecek şirketler ortaya konmamıştır. Sistemin küçük üreticiye hitap etmemesi ve yatırımcı için alternatif finansal enstrümanların en karlı yatırım aracı olma özelliklerini sürdürmeleri sistemin önündeki en önemli engeller olarak sayılabilir.

\subsection{Sistemin Uygulamasına Yönelik Sorunlara Çözüm Önerileri}

Lisanslı depoculuk sisteminin başarılı bir şekilde uygulanabilmesi için öncelikle makro ekonomik göstergelerin sağliklı olması gerekmektedir. Diğer taraftan, teknik ve altyap1 eksikliklerinin giderilmesi de gerekmektedir.

Makbuz senedini rehin alarak kredi sağlayacak olan bankaların sisteme dahil edilmesi ve sistem içerinde yer alan her bir birimin birbiriyle iletişimini sağlayacak bilişism ağının kurulması son derece önemlidir. Zira, makbuz senedi borsada sürekli olarak el değiştirebilecektir. Bu bağlamda sorun yaşanmaması için banka-borsa ve lisanslı depo üçgeni arasında sıkı bir ağ kurulması gerekmektedir. Ürün için sigorta sağlayacak şirketlerin hangi şartlarda sistemde yer alacaklarına da açıklık getirilmesi şarttır.

Türkiye'de lisanslı depoculuk sisteminin uygulanabilirliği mevcut şartlar altında oldukça zor gözükmektedir. Ancak sistemde rol alan kurum ve kuruluşlarla ilgili görev, yetki ve sorumluluklar ile teknik, hukuki ve bilişimle 
ilgili altyapı çalışmaları tamamlanırsa uygulamada uzun vadede tarım piyasalarının gelişmesinde başarı sağlanabilecektir.

\section{Sonuç}

Küreselleşme ve uluslararası rekabet koşullarında meydana gelen değişimler, Türkiye'nin tarım politikalarını oluştururken sadece iç dinamikleri değil, dış dinamikleri de dikkate almak durumunda bırakmaktadır. Tarımsal ürün piyasalarında dünya ile rekabet edebilmek için gelişmiş piyasaların oluşması şarttır. Bu nedenle, ürün borsaları ve lisanslı depoculuk sisteminin geliştirilmesi, tarım veri sistemi ve pazar enformasyon ağının kurulması açısından son derece önemlidir. Gelecekte rekabet, firmalar veya üreticiler arasında değil tedarik zincirleri arasında yaşanacaktır. Tedarik zinciri mal ve hizmetlerin tedarik aşamasından üretime ve nihai tüketiciye ulaşmasına kadar birbirini izleyen tüm halkaları kapsamaktadır. Sanayi ve Ticaret Bakanlığı'nca yasal altyapısı oluşturulan lisanslı depoculuk ve ürün borsaları, özellikle stoklama ve pazarlama halkaları ile dağıtım halkaları üzerinde görünen bir etki yapacaktır (Anonim, 2004).

Tarım piyasalarında eksikliği hissedilen lisanslı depoculuk sistemi ile; ürünlerinin standartlara göre borsa vasitasiyla makbuz (ürün) senetleri üzerinden alınıp satılması, ürünlerin sigorta edilmesi, tazmin fonu vasıtasıyla mudi menfaatlerinin güvence altına alınması, elektronik ürün ticaretine geçilmesi ve ihtilafların çözümünde bilirkişi ve tahkim yoluna gidilmesi gibi temel yenilikler getirilmiştir. Ancak lisanslı depoculuğun çalışabilmesi için tüm tarım ürünlerinde, gelişmiş spot piyasaların oluşturulması, ürün borsacılığının ulusal boyutta olması ve ticaret borsalarının işlevsel bir yapıya kavuşturulması şarttır (Anonim, 2009d). Türkiye'deki borsaların birbirleriyle ve dünya borsaları ile entegre olmaları açısından çağdaş iletişim ve haberleşme araçları ile donatılması ve gerekli ağın kurulması zorunludur. Aynı zamanda lisanslı depobanka ve borsa veri tabanı oluşturularak veri paylaşımı sağlanması sistemin sağlıklı işleyebilmesi ve makbuz senedi mülkiyetinin takibi açısından son derece önemlidir.

Lisanslı depoculuk sisteminin uygulanması, ürün borsacıllı̆ını geliştireceğinden Türkiye'yi AB ile müzakere sürecinde tarım, hayvancılık ve gıda konularında avantajlı konuma taşıyacaktır (Anonim, 2009e). Ürün İhtisas Borsacılığı ve Lisanslı Depoculuk Sistemleri, Vadeli İşlemler ve Opsiyon Borsalarının gelişimini olumlu etkileyecektir. 
Gelişmiş ülkelerde uygulanan lisanslı depoculuk sistemi ülkemizde de uygulamaya geçtiğinde, başta hububat, baklagiller, pamuk, findık ve zeytinyağ 1 olmak üzere Türkiye açısından son derece büyük öneme sahip ürünlerin ticaret hacminde, kalitesinde, arz ve talebin dengelenmesinde ve fiyatların istikrarının sağlanmasında büyük gelişmeler kaydedilecektir (Anonim, 2009f).

Türkiye'de tarım ürünleri piyasasında en önemli sorun arzın talebe gecikmeli uyum sağlamasıdır. Hasat sezonu üreticilerin yeterli depolama imkanları olmadığından, bu durum üretici yönünden düşük gelir, tüccar için de sıkışmış bir pazar yaratmaktadır. Bu nedenle lisanslı depoculuk konusunda adımların atılması gerekmektedir. Globalleşen dünyada pazarın tek ve rekabetin çok olduğu göz önüne alınırsa; dış etkenler nedeniyle, alternatif politika ve destekleme araçları giderek sınırlanan Türkiye de etkin, verimli ve sürdürülebilir bir tarım sektörü için lisanslı depoculuk sistemini bir an önce hayata geçirmelidir. Sistemde başarının hemen sağlanamayacağ 1 unutulmamalıdır. Bulgaristan'da lisanslı depoculuk sistemi 1997 y1lında başlamış, olumlu sonuçlar 2001-2002 yıllarında alınmaya başlanmıştır. Lisanslı Depoculuk Sistemi ile tarım piyasaları yeni bir ivme kazanacaktır.

\section{Kaynaklar}

Anonim (2004), II. Tarım Şurası VI. Komisyon Üretim ve Pazarlama Politikaları Komisyon Raporu, http://tarimsurasi.tarim.gov.tr/PDFLER/VI.Konisyon.pdf, 18.03.2010.

Anonim (2005), Resmi Gazete, 17 Şubat 2005, Sayı 25730, Tarım Ürünleri Lisanslı

Depoculuk Kanunu, Kanun No:5300.

http://www.alomaliye.com/5300sayilikanuntarimurundepo.htm, 10.03.2009.

Anonim (2007), $\quad$ http://www.tarimsalbilgi.org/forums/tmodan35ildekiragarantili lisanslidepo-t629.0.html, 10.03.2009.

Anonim (2009a), Ankara Ticaret Borsas1, http://www.atb.gov.tr, 24.03.2009.

Anonim (2009b), Tarım Reformu Uygulama Projesi, http://www.arip.org.tr, 20.03.2009.

Anonim (2009c), Lisansli Depoculuk, http://www.tumgazeteler.com/?a=4602165, 12.02.2009.

Anonim (2009d), Türkiye Ziraat Odaları Birliği, http://www.tzob.gov.tr, 12.02.2009.

Anonim (2009e), Cine Tarım Agricultural Inc., http://www.cine-tarim.com.tr, 24.03.2009.

Anonim (2009f), İzmir Ticaret Borsası, http://www.itb.org.tr, 24.03.2009. 
Karabaş, S. \& Gürler, A.Z. / Sosyal Bilimler Araştırmaları Dergisi. 1, (2010): 196-210

Anonim (2010), Lisanslı Depoculuk İçin Şirket Kuruluyor, http://www.tumgazeteler.com/?a=6115522, 23.05.2010.

Coulter, J. and Onumah G. (2002), "Role of Warehouse Receipt Systems in Enhanced Commodity Marketing and Rural Livelihoods in Africa", Food Policy 27 (2002) pp. 319-337.

Demirbilek, S. Koç, C. Arslan, M. (2006). "Ticaret Borsalarından Gerçek Borsaya Genel Yaklaşım-Tarımsal Ürün Piyasalarının Liberalizasyonu".

Erbay, E.R. (2006), "Lisanslı Depoculuk ve Ürün Borsalarının Tarım Ürünleri Piyasalarına Etkileri: Trakya Bölgesi Örneği”, Türkiye VII. Tarım Ekonomisi Kongresi, Antalya.

Faber Nynke, Rene (Marinus) B.M. De Koster, Steef L.Van De Velde. (2002), "Linking Warehouse Complexity to Warehouse Planning and Control Structure", Industrial Journal of Physical Distribution\&Logistics Management, Vol 32, no 5, pp.381-395.

Grange D. M. (2002), Feasibility Study for a Regional Warehouse Receipt

Program for Mali, Senegal and Guinea. http://pdf.usaid.gov/pdf docs/PNACT862.pdf, 20.04.2010.

Gürler, Z. (2008), Tarım Ekonomisi Ders Kitabı, ISBN 978-605-395-067-7.

Hekimoğlu, B. ve Altındeğer, M. (2006), Tarım Ürünleri Lisanslı Depoculuk Sistemi ve Etkileri, Samsun Valiliği Tarım İl Müdürlüğü.

İnan, İ.H. (2001), Tarım Ekonomisi ve İşletmeciliği, Yayın No: ISBN 975-93281-0-0, Avc1 Ofset, İstanbul.

İnan, İ.H. Gaytancıoğlu, O. Erbay, R. Yılmaz, F. (2003), Gelişmiş Ülkelerde Tarım Piyasalarının Organizasyonu, İstanbul Ticaret Odası, Yayın No: 200353, Ankara.

Lacroix, R. and Varangis, P. (1996), "Using Warehouse Receipts in Developing and Transition Economies”, Finance\&Development $\quad$ September 1996. Number: 3, http://www.imf.org/external/pubs/ft/fandd/1996/09/pdf/lacroix.pdf, 21.03.2010.

Ulas, D. (2007), EU Market Access: The Way Of Licensed Warehousing System for Turkish Food Producers and Exporters. "International Marketing and International Trade of Quality Food Products (Seminar)" Bologna, Italy,

http://ageconsearch.umn.edu/bitstream/7860/1/pp07ul01.pdf,21.03.2010

Uras, G. (2006), "Lisanslı Depolar", Milliyet Gazetesi, 20.03.2009.

USAID (2005), Warehouse Receipts Systems, Rural Agricultural Finance Specialty Topic Series.

http://www.microlinks.org/ev02.php?ID=13176201\&ID2=DOTOPIC, 10.02.2010. 